\title{
Determination of the Irrigation Regimen for an Avocado Plantation in Spring and Autumn
}

\author{
E. Lahav ${ }^{\mathrm{A}}$ and D. Kalmar ${ }^{\mathrm{B}}$ \\ ${ }^{A}$ Department of Subtropical Horticulture, Agricultural Research Organisation, \\ The Volcani Center, P.O.B. 6, Bet Dagan, Israel. \\ ${ }^{B}$ Department of Environmental Physiology and Irrigation, Agricultural Research Organization, \\ The Volcani Center, P.O.B. 6, Bet Dagan, Israel.
}

Abstract

An irrigation experiment was conducted with three cultivars (Hass, Ettinger and Fuerte) in the avocado plantation of the Akko Experiment Station, Israel, during 1974-80 to determine the effect of irrigation regimen in spring and autumn on tree growth and productivity.

Two treatments (wet and dry) were tested in the spring and in the autumn. In spring the trees receiving the wet treatment were irrigated when the tension at a soil depth of $30 \mathrm{~cm}$ reached $25 \mathrm{cbar}$ (250 MPa), while those in the dry treatment were irrigated at 40 cbar tension. The same wet treatment was also applied in the autumn, while in the dry treatment the trees were not irrigated until the fruit reached elasticity at noon.

The water regimen in the spring affected tree growth slightly, but in cvv. Hass and Ettinger the absolute and relative growth was higher in the spring dry treatment than in the wet. Trees grew faster under the autumn wet regimen than with the autumn dry regimen.

The effect of irrigation regimen on yield, fruit size and export quality was light. Only with cv. Ettinger were higher yields recorded from trees irrigated with the dry-wet regimen. The autumn water stress sometimes decreased fruit size, but size was affected much more by the tree yield than by the irrigation regimen.

It seems that the regimens in spring and autumn do not increase the productivity of avocado trees. However, equivalent yields of the same quality can be obtained with reduced water amounts, by using the water more efficiently.

\section{Introduction}

In an irrigation experiment conducted in the Western Galilee, Israel, it was found that it is possible to irrigate avocado plantations at wide intervals (up to 21 days) and with reduced water amounts of $6700 \mathrm{~m}^{3} /$ ha per year (in addition to 6000 $\mathrm{m}^{3}$ /ha per year of rain), without impairing the fruit yield or quality (Lahav and Kalmar 1977). That experiment related to heavy clay soils and to the midsummer dry season. It disregarded the special problems of the transitional seasons of spring and autumn.

The irrigation regimen in the spring is important, since in this season flowering, fruit set and fruit drop occur. Water is a very important factor determining excessive drop of flowers, fruitlets and young fruit. Because transpiration exceeds water uptake and translocation from the soil, a negative water balance develops in the avocado canopy during the day (Schroeder and Wieland 1956). It is assumed that the flower and the fruitlet are extremely sensitive to these partial water deficiencies. The negative water balance is accelerated in a hot and dry climate. 
It is sometimes impossible to irrigate frequently in the spring. In the heavy soils on which avocado is frequently grown, the danger of overwetting exists and, as a result, aeration of the upper soil layer is impaired. The upper layer contains most of the avocado tree's roots and its blockage therefore also affects the air flow to the lower soil layers. When the supply of oxygen to the roots is limited, nutrient uptake may also be reduced (Slowik et al. 1979), and thus the synthesis of hormones preventing fruit drop may be harmed. The reduced soil aeration may also increase the avocado tree's susceptibility to root rot (Wager 1942).

Over the years, some information has been gained concerning the drop of avocado flowers and young fruits (Lahav and Zamet 1975). It seems that the easiest way to increase avocado productivity is by avoiding or reducing the fruit drop in late spring or early summer. In that season the effect of winter precipitation is reduced, and the effect of the factors controlling the negative water balance of the tree is increased. It is therefore imperative that water stress is avoided in this critical season. However, to the best of our knowledge, the effect of irrigation regimen in the spring on fruit drop and the final yield has not been tested experimentally.

It is well known that the summer irrigation regimen may affect fruit size and that, by frequent irrigations, the size and export quality of cv. Hass can be improved (Lahav and Kalmar 1977). It is also known that, during autumn, the rate of fruit growth slows down. In lemon trees, water stress in the autumn altered the flowering habits in the following spring and increased the yield markedly (Nir et al. 1972).

The experiments and field trials with the avocado tree conducted so far have related mainly to the summer season and have disregarded the special problems of irrigation in the spring and autumn. The following experiment was therefore conducted to test avocado irrigation regimens in spring and autumn with the further aim of achieving an additional saving of water.

\section{Materials and Methods}

The experiment was conducted in an avocado plantation on low lime-grumusol with $60-63 \%$ clay in all layers down to $150 \mathrm{~cm}$. The plantation was 11 years old and included the cultivars 'Ettinger', 'Fuerte' and 'Hass'. The area comprised 20 experimental plots with nine measured trees (6 by $6 \mathrm{~m}$ ) in each and a double guard row. Under-the-canopy sprinkling was employed, with one sprinkler per tree. The rate was $7 \mathrm{~mm} / \mathrm{h}$ of good quality water (electrical conductivity $500-800 \mu \mathrm{S} / \mathrm{cm}$; $50 \mathrm{mg}$ chloride/1). The experiment comprised four treatments in five randomized blocks.

Two treatments, wet and dry, were given in the spring and two in the autumn. The treatments were determined according to the soil water tension, measured by tensiometers placed at a depth of $30 \mathrm{~cm}$ (Table 1). Spring treatments were applied until the end of June, the time of termination of fruitlet drop. During the summer a 21-day interval was employed, as suggested by the results of the previous experiment (Kalmar and Lahav 1977; Lahav and Kalmar 1977). However, in 'on years' the interval was reduced to 14 days. The autumn treatments were instituted at the beginning of September. Because of the difference in irrigation intervals, different water amounts were given (Table 2). Since the avocado is an alternate-bearing tree, the experiment lasted 7 years. In each year, trunk circumference was recorded $20 \mathrm{~cm}$ above the graft union as a general estimate of tree size. Flowering intensity and new flush length were estimated in 1975.

Since cv. Ettinger and sometimes also cv. Fuerte were picked before the first rainfall (generally in late October), the fruit was always harvested 2-3 days after the irrigation on the 'dry autumn treatment'. The fruits of each tree were counted and weighed. In years of heavy yield, the fruit was graded at the packing house and the average fruit size and export quality were determined. In years of low yield, the fruit was graded according to the autumn treatments only. The effect of the treatments on fruit drop of cv. Hass was determined in 1975, 1976 and 1980. Shelf life of cv. Ettinger was determined in 1975, and of cv. Fuerte in 1976, after 9 days of storage at $5^{\circ} \mathrm{C}$. 


\section{Results}

\section{Water Amounts}

The duration of the irrigation season differed from year to year, depending on the winter precipitation, and the annual water amounts differed accordingly (see Table 2). The average annual water amount varied between $7440 \mathrm{~m}^{3} / \mathrm{ha}$ in the wet-wet (spring-autumn) treatment and $5380 \mathrm{~m}^{3} / \mathrm{ha}$ in the dry-dry treatment. In the wet-wet treatment about one-third of the annual total was given in the spring,

Table 1. Soil water tension and irrigation intervals according to the treatments applied

\begin{tabular}{lcccc}
\hline Season & Treatment & $\begin{array}{c}\text { Water } \\
\text { tension (cbar) }\end{array}$ & $\begin{array}{c}\text { Av. irrigation } \\
\text { interval (days) }\end{array}$ & $\begin{array}{c}\text { No. of irrigations } \\
\text { per season }\end{array}$ \\
\hline Spring ${ }^{\text {A }}$ & Wet & 25 & $7 \pm 3$ & $10 \pm 2$ \\
& Dry & 50 & $16 \pm 3$ & $3 \pm 2$ \\
\multirow{3}{*}{ Autumn } & Wet & 25 & $6 \pm 3$ & $10 \pm 3$ \\
& Dry & B & $25 \pm 5$ & $2 \pm 1$ \\
\hline
\end{tabular}

A On hot and dry days, when the relative humidity was less than $30 \%$, a supplementary irrigation was given to both wet and dry treatments.

${ }^{B}$ In the autumn dry treatment the trees were stressed until $\mathrm{cv}$. Ettinger fruit showed elasticity at noon.

Table 2. Average seasonal water amounts (excluding rainfall) and the relationship between the water deficit and the evapotranspiration from a Class $A$ pan $\left(E_{\mathrm{t}} / E_{\mathrm{o}}\right)$

\begin{tabular}{|c|c|c|c|c|c|c|c|c|c|c|}
\hline & \multicolumn{5}{|c|}{ Irrigation season and treatment } & \multicolumn{5}{|c|}{ Irrigation regimen } \\
\hline & \multicolumn{2}{|c|}{ Spring } & \multirow[t]{2}{*}{ Summer } & \multicolumn{2}{|c|}{ Autumn } & \multirow{2}{*}{$\begin{array}{r}\text { Spring: } \\
\text { Autumn: }\end{array}$} & \multirow{2}{*}{$\begin{array}{l}\text { Wet } \\
\text { Wet }\end{array}$} & \multirow{2}{*}{$\begin{array}{l}\text { Wet } \\
\text { Dry }\end{array}$} & \multirow{2}{*}{$\begin{array}{l}\text { Dry } \\
\text { Wet }\end{array}$} & \multirow{2}{*}{$\begin{array}{l}\text { Dry } \\
\text { Dry }\end{array}$} \\
\hline & Wet & Dry & & Wet & Dry & & & & & \\
\hline Av. water amount & 2420 & 17 & 27 & 2340 & 990 & & 7440 & 6070 & 6760 & 5380 \\
\hline$E_{\mathrm{t}} / E_{\mathrm{o}}$ & 0.42 & $0 \cdot 30$ & 0.61 & 0.68 & $0 \cdot 28$ & & $0 \cdot 54$ & $0 \cdot 44$ & $0 \cdot 49$ & 0.39 \\
\hline
\end{tabular}

one-third in the summer and one-third in the autumn, while in the dry-dry irrigation regimens less than one-third was applied in the spring and only 16-18\% of the total was applied in the autumn. The water amount applied in the wet-wet plots was equivalent to that amount given in commercial avocado plantations, as is indicated by the relationship between the water deficit and the evaporation from a class A pan, $E_{\mathrm{t}} / E_{\mathrm{Q}}=0.54$. With the three other treatments, the water amounts and the irrigation factors were much lower than those customarily used.

\section{Trunk Circumference}

Tree growth was uniform at the start of the experiment, but was influenced strongly by the irrigation regimen (Table 3). Starting from the first year, the increment in trunk circumference in the autumn wet treatments was much greater in all three cultivars than in the autumn dry treatments. The average increment from the beginning to the end of the experiments was $142 \mathrm{~mm}$ in the autumn wet 
treatments compared with $117 \mathrm{~mm}$ in the dry treatments; the smallest increase was always in the dry-dry regimen. More absolute and relative growth was found in the trees of cvv. Ettinger and Hass under the dry-wet regimen than in those with the wet-wet regimen.

\section{Flowering and Flush}

The effect of treatment on flowering and on new flush growth, measured in spring of 1975, was small and negligible in all three cultivars.

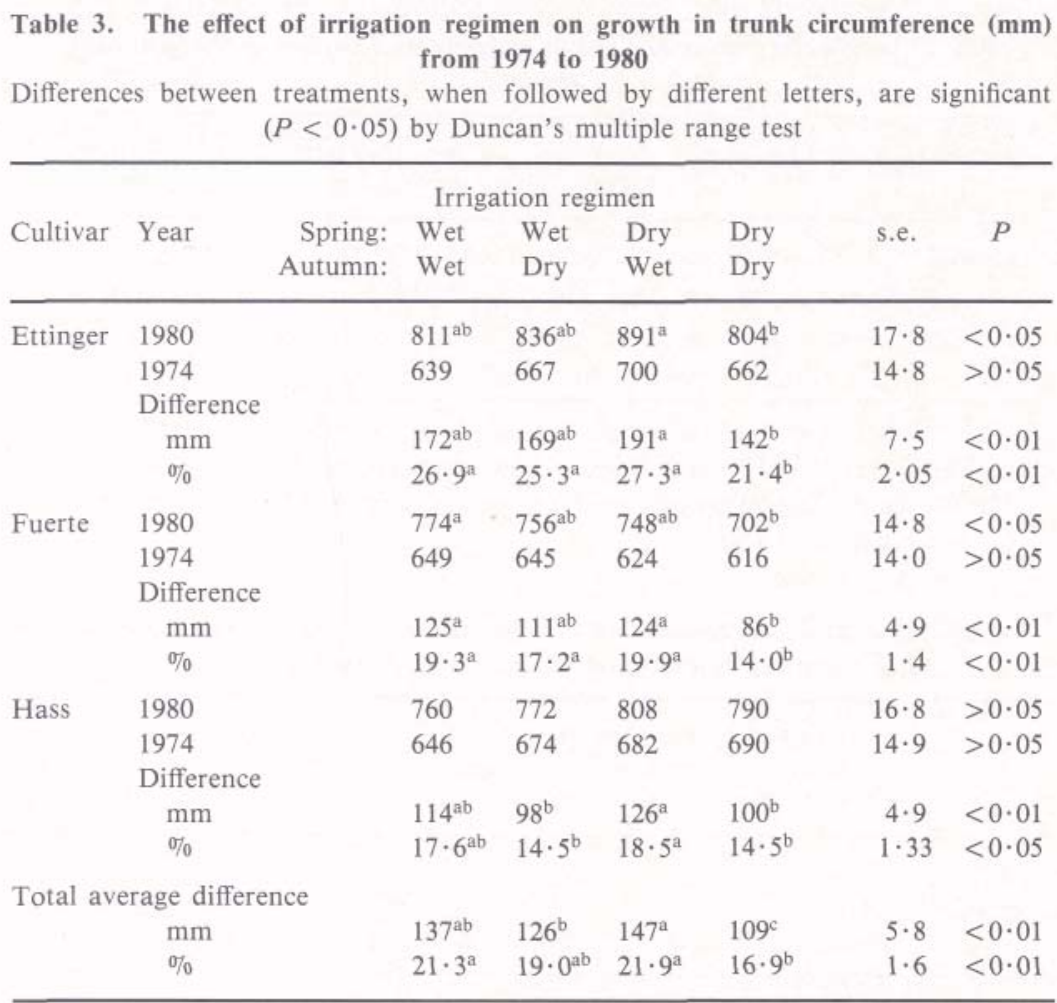

\section{Fruit Yield}

The effect of irrigation treatment on yield of fruit was relatively small (Table 4). Only with cv. Ettinger was any significant $(P<0.05)$ influence found, where over the 7 years of the experiment the average yield in the dry-wet regimen was $13 \mathrm{~kg} /$ tree higher than that in the wet-wet regimen. In most years a higher yield was recorded in the trees irrigated with the dry-wet regimen. This increase was mainly the result of greater fruit weight (Table 5). With cv. Fuerte the annual differences were small. The 7-year average suggested a higher yield in the wet-wet regimen compared with the dry-dry regimen, but the difference was not significant. Both fruit weight and number influenced the yield. With cv. Hass, the differences in average yields were small and non-significant.

\section{Fruit Drop}

Water stress in either spring or autumn resulted in accelerated fruit drop in cv. Hass in 1975 and 1980, when there were wind-storms in the autumn (Table 6). 
Table 4. The effect of irrigation regimen on the yield of avocado fruit $(\mathrm{kg} / \mathrm{tree})$ in 7 years

Differences between treatments when followed by different letters are significant $(P<0.05)$ by Duncan's multiple range test

\begin{tabular}{|c|c|c|c|c|c|c|c|c|}
\hline \multirow{3}{*}{ Cultivar } & \multirow{3}{*}{ Year } & \multirow{3}{*}{$\begin{array}{l}\text { Spring: } \\
\text { Autumn: }\end{array}$} & \multirow{3}{*}{$\begin{array}{l}\text { Wet } \\
\text { Wet }\end{array}$} & \multicolumn{2}{|c|}{ Irrigation regimen } & \multirow{3}{*}{$\begin{array}{l}\text { Dry } \\
\text { Dry }\end{array}$} & \multirow{3}{*}{ s.e. } & \multirow{3}{*}{$P$} \\
\hline & & & & Wet & Dry & & & \\
\hline & & & & Dry & Wet & & & \\
\hline \multirow{8}{*}{$\begin{array}{l}\text { Ettinger } \\
>0.05\end{array}$} & 1974 & & $39 \cdot 9$ & $42 \cdot 5$ & $42 \cdot 5$ & $44 \cdot 1$ & $41 \cdot 0$ & $7 \cdot 62$ \\
\hline & 1975 & & $78 \cdot 5$ & $78 \cdot 6$ & $93 \cdot 0$ & $75 \cdot 3$ & $6 \cdot 94$ & $>0.05$ \\
\hline & 1976 & & $33 \cdot 0$ & $38 \cdot 5$ & $35 \cdot 5$ & $29 \cdot 9$ & $10 \cdot 42$ & $>0.05$ \\
\hline & 1977 & & $32 \cdot 5$ & $42 \cdot 1$ & $59 \cdot 3$ & $49 \cdot 5$ & $9 \cdot 18$ & $>0.05$ \\
\hline & 1978 & & $92 \cdot 5$ & $112 \cdot 9$ & $115 \cdot 3$ & $115 \cdot 3$ & $9 \cdot 07$ & $>0.05$ \\
\hline & 1979 & & $60 \cdot 9^{b}$ & $38 \cdot 3^{\mathrm{a}}$ & $65 \cdot 9^{b}$ & $45 \cdot 8^{\mathrm{a}}$ & $7 \cdot 62$ & $<0.05$ \\
\hline & 1980 & & $29 \cdot 0$ & $38 \cdot 7$ & $38 \cdot 8$ & $37 \cdot 5$ & $4 \cdot 93$ & $>0.05$ \\
\hline & Av. & & $52 \cdot 3^{b}$ & $55 \cdot 9^{\mathrm{b}}$ & $65 \cdot 6^{a}$ & $56 \cdot 3^{b}$ & $2 \cdot 65$ & $<0.05$ \\
\hline \multirow[t]{8}{*}{ Fuerte } & 1974 & & $46 \cdot 4$ & $42 \cdot 9$ & $40 \cdot 1$ & $44 \cdot 3$ & $5 \cdot 58$ & $>0.05$ \\
\hline & 1975 & & $28 \cdot 7$ & $31 \cdot 7$ & $28 \cdot 9$ & $23 \cdot 4$ & $5 \cdot 08$ & $>0.05$ \\
\hline & 1976 & & $47 \cdot 6$ & $40 \cdot 5$ & $44 \cdot 6$ & $44 \cdot 7$ & $7 \cdot 63$ & $>0.05$ \\
\hline & 1977 & & $57 \cdot 5$ & $61 \cdot 5$ & $64 \cdot 5$ & $45 \cdot 2$ & $6 \cdot 72$ & $>0.05$ \\
\hline & 1978 & & $84 \cdot 3$ & $78 \cdot 8$ & $68 \cdot 3$ & $83 \cdot 3$ & $6 \cdot 64$ & $>0.05$ \\
\hline & 1979 & & $8 \cdot 3$ & $17 \cdot 2$ & $8 \cdot 4$ & $7 \cdot 6$ & $5 \cdot 58$ & $>0.05$ \\
\hline & 1980 & & $32 \cdot 5$ & $33 \cdot 2$ & $31 \cdot 7$ & $29 \cdot 7$ & $3 \cdot 61$ & $>0.05$ \\
\hline & Av. & & $45 \cdot 0$ & $43 \cdot 7$ & $40 \cdot 9$ & $39 \cdot 7$ & 1.94 & $>0.05$ \\
\hline \multirow[t]{8}{*}{ Hass } & 1974 & & $48 \cdot 9$ & $48 \cdot 0$ & $63 \cdot 6$ & $49 \cdot 9$ & $7 \cdot 28$ & $>0.05$ \\
\hline & 1975 & & $47 \cdot 2$ & $40 \cdot 1$ & $38 \cdot 4$ & $34 \cdot 5$ & $6 \cdot 63$ & $>0.05$ \\
\hline & 1976 & & $75 \cdot 7$ & $83 \cdot 7$ & $86 \cdot 4$ & $83 \cdot 5$ & $9 \cdot 95$ & $>0.05$ \\
\hline & 1977 & & $71 \cdot 8$ & $58 \cdot 7$ & $58 \cdot 9$ & $58 \cdot 8$ & $8 \cdot 77$ & $>0.05$ \\
\hline & 1978 & & $65 \cdot 3$ & $63 \cdot 7$ & $75 \cdot 4$ & $72 \cdot 1$ & $8 \cdot 67$ & $>0.05$ \\
\hline & 1979 & & $46 \cdot 7$ & $51 \cdot 1$ & $38 \cdot 9$ & $53 \cdot 7$ & $7 \cdot 28$ & $>0.05$ \\
\hline & 1980 & & $30 \cdot 5^{\mathrm{ab}}$ & $37 \cdot 9^{\mathrm{a}}$ & $21 \cdot 4^{b}$ & $31 \cdot 6^{\mathrm{ab}}$ & $4 \cdot 71$ & $<0.05$ \\
\hline & Av. & & $55 \cdot 2$ & $54 \cdot 7$ & $54 \cdot 7$ & $54 \cdot 9$ & $2 \cdot 54$ & $>0.05$ \\
\hline \multicolumn{2}{|c|}{ Total average } & & $50 \cdot 8$ & $51 \cdot 4$ & $53 \cdot 4$ & $50 \cdot 3$ & $1 \cdot 2$ & $>0.05$ \\
\hline
\end{tabular}

Table 5. The effect of irrigation treatment on the number of fruit per tree and on the average fruit weight $(g)$ over 6 years

Differences between treatments when followed by different letters are significant $(P<0.05)$ by Duncan's multiple range test

\begin{tabular}{|c|c|c|c|c|c|c|c|}
\hline \multirow{3}{*}{ Cultivar } & \multirow{3}{*}{$\begin{array}{l}\text { Spring: } \\
\text { Autumn: }\end{array}$} & \multirow{3}{*}{$\begin{array}{l}\text { Wet } \\
\text { Wet }\end{array}$} & \multicolumn{3}{|c|}{ Irrigation regimen } & \multirow{3}{*}{ s.e. } & \multirow{3}{*}{$P$} \\
\hline & & & Wet & Dry & Dry & & \\
\hline & & & & Wet & Dry & & \\
\hline \multicolumn{8}{|c|}{ Number of fruits/tree } \\
\hline Ettinger & & $168^{b}$ & $180^{a b}$ & $207^{\mathrm{a}}$ & $182^{\mathrm{ab}}$ & $10 \cdot 0$ & $<0.05$ \\
\hline Fuerte & & 150 & 140 & 133 & 130 & $8 \cdot 0$ & $>0.05$ \\
\hline Hass & & 300 & 286 & 267 & 282 & $11 \cdot 6$ & $>0.05$ \\
\hline Average & & 206 & 202 & 202 & 198 & $3 \cdot 1$ & $>0.05$ \\
\hline \multicolumn{8}{|c|}{ Fruit weight $(g)$} \\
\hline Ettinger & & 278 & 290 & 302 & 298 & $10 \cdot 2$ & $>0.05$ \\
\hline Fuerte & & $263^{\mathrm{a}}$ & $255^{a b}$ & $262^{\mathrm{a}}$ & $241^{b}$ & $6 \cdot 5$ & $<0.05$ \\
\hline Hass $^{A}$ & & 168 & 177 & 168 & 177 & $4 \cdot 6$ & $>0.05$ \\
\hline Average & & 236 & 241 & 244 & 239 & $5 \cdot 2$ & $>0.05$ \\
\hline
\end{tabular}

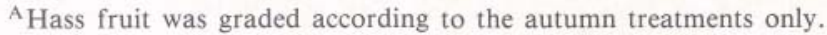




\section{Export Quality}

The fruit of all treatments was of good export quality, even that of cv. Ettinger, which was water-stressed in autumn. The fruit elasticity recorded 2-3 days before picking did not influence the export quality of the fruit. The percentage of fruit exported was lower in those Ettinger and Fuerte trees which were irrigated by the wet spring treatment, and especially by the wet-wet regimen (Table 7).

\begin{tabular}{|c|c|c|c|c|c|}
\hline \multirow{3}{*}{ Year } & \multicolumn{5}{|c|}{ Irrigation regimen } \\
\hline & Spring: & Wet & Wet & Dry & Dry \\
\hline & Autumn: & Wet & Dry & Wet & Dry \\
\hline 1975 & & 15 & 22 & 30 & 35 \\
\hline 1976 & & 7 & 5 & 5 & 5 \\
\hline 1980 & & 11 & 15 & 9 & 17 \\
\hline Average & & 11 & 14 & 15 & 19 \\
\hline
\end{tabular}

Table 7. The effect of irrigation regimen on the percentage of fruit of export quality (6-year average)

\begin{tabular}{lccccc}
\hline \multirow{2}{*}{ Cultivar } & \multicolumn{5}{c}{ Irrigation regimen } \\
& $\begin{array}{r}\text { Spring: } \\
\text { Autumn: }\end{array}$ & Wet & Wet & Dety & Dry \\
& & Dry & Wet & Dry \\
\hline Ettinger & & $71 \cdot 8$ & $75 \cdot 2$ & $80 \cdot 4$ & $79 \cdot 2$ \\
Fuerte & & $76 \cdot 2$ & $83 \cdot 9$ & $86 \cdot 9$ & $85 \cdot 0$ \\
Hass & & $88 \cdot 0$ & $87 \cdot 5$ & $88 \cdot 0$ & $87 \cdot 5$ \\
Average & & $78 \cdot 7$ & $82 \cdot 2$ & $85 \cdot 1$ & $83 \cdot 9$ \\
\hline
\end{tabular}

\section{Discussion}

In the present experiment, as well as in the previous one (Kalmar and Lahav 1977; Lahav and Kalmar 1977), it was found that good-yielding avocado trees can give good yield with water duties significantly lower than those customarily used. An annual amount of $6700 \mathrm{~m}^{3} / \mathrm{ha}$ (in addition to $6000 \mathrm{~m}^{3} / \mathrm{ha}$ of rainfall) proved to be sufficient for avocado trees grown on clay soils. In contrast to the previous work, most of the influence was achieved in cvv. Ettinger and Fuerte, since their fruit is picked early in the season, before the onset of the winter rains. Since the Hass fruit is picked at the end of winter, the effect of irrigation regimen was greatly masked. As found previously (Lahav and Kalmar 1977), the combined effect of precipitation and adequate temperatures resulted in accelerated fruit growth of cv. Hass, and therefore the reduced fruit growth caused by the autumn water stress disappeared. Hence, we did not observe any treatment effect on Hass fruit growth and percentage of export quality fruit. In contrast to our previous work, the treatments did not affect the alternate-bearing habit of cv. Hass (Lahav and Kalmar 1977). 
Flowering was not induced by autumn water stress and yields in the following year were no higher, in contrast to what occurred with a similar treatment in lemons (Nir et al. 1972). The negative effect of the water stress was expressed in the decreased fruit size of cv. Fuerte and the increased fruit drop of cv. Hass; however, it was not significant enough to reduce the total yield. It is concluded that water can be saved in the autumn, but an irrigation interval of 1 month is too long and has some negative effects. The main advantages of the late-season water stress are, therefore, the more convenient soil condition at the start of the coming winter rainy season (i.e. the soil's greater water capacity), the decreased water excess, and, of course, the savings in water.

The major objective of the present experiment was to test the sensitivity of the avocado tree to the irrigation regimen in spring, a season in which flowering, fruit set and fruit drop occur. The shorter irrigation intervals in the spring had no effect on the avocado tree grown in the heavy clay soils. The wet irrigation regimens did not produce any advantage over the dry treatments; we even recorded the opposite effect. The greatest trunk growth (in cvv. Ettinger and Hass) and the highest yield in the cv. Ettinger were obtained in the trees receiving the dry-wet treatment, not the wet-wet treatment, despite the fact that a negative relationship may exist between tree growth and fruiting. In addition, the percentage of fruit of export quality was higher in the Ettinger and Fuerte trees irrigated with the dry-wet regimen.

Water excess in the spring affected cv. Ettinger more than the other cultivars. Generally, the higher the yield, the smaller the individual fruits. However, in cv. Ettinger, despite the low yields in the trees irrigated often in the spring, the fruit also was relatively small. We can therefore recommend shortening the irrigation interval with the aim of increasing fruit size in July-August (northern hemisphere) when the fruit growth rate is rapid (Lahav and Kalmar 1977). Shortening the irrigation interval in the spring had no advantage, while the effect in autumn was relatively small because of the slow rate of growth of the fruit in that season.

Frequent irrigation in the spring did not produce favourable results from the experimental area (Western Galilee), as there is a considerable underground reservoir of water after the winter wet season. The effect of this great amount of available moisture is to delay water stress in the soil and therefore normal fruit growth rate is maintained until June (Lahav and Kalmar 1977). Similar conclusions on a possible savings in water in the early spring were drawn in an irrigation experiment with apples in the U.S.A. (Tukey et al. 1980).

Frequent spring irrigations may bring about only reduced aeration, cooling of the soil, and root destruction. An irrigation regimen which dries the soil leads to a favourable soil structure, whereas destruction of the structure can be caused by short irrigation intervals which represent, in fact, a regimen without any drying (Kalmar 1979). The avocado plantations in Israel do not bear fruit according to their yielding capacity. The results of the present experiment, as well as the previous one (Kalmar and Lahav 1977; Lahav and Kalmar 1977), show that the irrigation regimen in spring and autumn is not the limiting factor for increasing avocado yields. On the contrary, the same yield with the same fruit quality can be achieved with reduced water amounts and more efficient use. 


\section{References}

Kalmar, D. (1979). The dynamics of a heavy clay soil. Ph.D Thesis, Hebrew University, Jerusalem. Kalmar, D., and Lahav, E. (1977). Water requirements of avocado in Israel. I. Tree and soil parameters. Aust. J. Agric. Res. 28, 859-68.

Lahav, E., and Kalmar, D. (1977). Water requirements of avocado in Israel. II. Influence on yield, fruit growth and oil content. Aust. J. Agric. Res. 28, 869-77.

Lahav, E., and Zamet, D. (1975). [Flower, fruitlet and fruit abscission in avocado trees.] Res. Rep. on Subtropical Fruit Trees, Spec. Publ. Agric. Res. Org., Bet Dagan No. 65, 57-63. (In Hebrew, with English summary.)

Nir, I., Goren, R., and Leshem, B. (1972). Effects of water stress, gibberellic acid and CCC on flower differentiation in "Eureka" lemon trees. J. Am. Soc. Hortic. Sci. 97, 774-8.

Schroeder, C. A., and Wieland, P. A. (1956). Diurnal fluctuation in size in various parts of the avocado tree and fruit. Proc Am. Soc. Hortic. Sci. 68, 253-8.

Slowik, K., Labanauskas, C. K., Stolzy, L. H., and Zentmyer, G. A. (1979). Influence of rootstocks, soil oxygen, and soil moisture on the uptake and translocation of nutrients in young avocado plants. J. Am. Soc. Hortic. 104, 172-5.

Tukey, R. B., Lowell, G., and Larsen, F. E. (1980). [Water management, a different approach to irrigation.] Alón haNotea 34, 651-6. (In Hebrew).

Wager, V. A. (1942). Phytophthora cinnamomi and wet soil in relation to the dying-back of avocado trees. Hilgardia 14, 519-32.

Manuscript received 4 January 1983, accepted 22 June 1983 